\title{
The Formation of Tourist Friendly Destination Concept in Kuala Lumpur
}

\author{
Ahmad Nazrin Aris Anuar ${ }^{1,2}$, Habibah Ahmad², Hamzah Jusoh² \& Mohd Yusof Hussain² \\ ${ }^{1}$ Centre of Studies Park \& Amenity Management, Faculty of Architecture, Planning \& Surveying, Universiti \\ Teknologi MARA, Shah Alam, Selangor Darul Ehsan, Malaysia \\ 2 School of Social, Development and Environment, Faculty of Social Sciences and Humanities, National \\ University of Malaysia, Bangi, Selangor Darul Ehsan, Malaysia \\ Correspondence: Ahmad Nazrin Aris Anuar, Centre of Studies Park \& Amenity Management, Faculty of \\ Architecture, Planning \& Surveying, Universiti Teknologi MARA, Shah Alam, Selangor Darul Ehsan, Malaysia. \\ Tel: 60-35-521-1544. E-mail: aek_2751@yahoo.com
}

\author{
Received: June 21, 2013 Accepted: August 27, 2013 Online Published: October 29, 2013 \\ doi:10.5539/ass.v9n15p166 URL: http://dx.doi.org/ass.v9n15p166
}

\begin{abstract}
This paper discusses the formation of tourist friendly destination concept in Kuala Lumpur. A total of 22 respondents has been interviewed, and the selection of respondents was based on four groups, decision-makers who involved in the planning and tourism development in Kuala Lumpur: the government sector, private sector, non-profit sector (associations) and professional consultants. From this process, the respondents have an opinion about the role of the respondents in their organizations concerning the formation the concept of tourist friendly destination in Kuala Lumpur, their understanding the concept of tourist friendly destination as well as the identification of the underlying component conceptualization tourist friendly destination.
\end{abstract}

Keywords: city tourism, Kuala Lumpur, planning and tourism development, tourist friendly destination

\section{Introduction}

The success of a tourism destination depends on offering something unique and different from other tourism destinations (Godfrey \& Clarke, 2000). To achieve success, Heath and Wall (1992) explained that tourism destinations have to be more creative and produce a unique of tourism system in tandem with producing a viable tourism destination. This is because every tourism destination cannot appeal to every tourist; because each tourist feels that they need to break through a variety of contexts and experiences (Dolnicar, 2008). However, the tourism industry of the 21 st century shows a more positive paradigm shift that is not simply based on a visit or destination, but more on the experience offered in the tourism destination (Kozak, 1999; Lipman, 2007). Thus, the concept of a tourist-friendly destination is seen as one a concept-oriented approach that treats tourists as customers (Anuar et al., 2012a). According to Lipman (2007), the tourists themselves choose a tourism destination when guided by a desire to learn, explore new experiences, and add meaning to their lives through the travel experience.

The introduction of tourist friendly destination concept in the city tourism is much-needed. This is a tourist oriented customer concept, where tourists choose their own activities, products, and space if they meet the demands and desired experience (Anuar et al., 2012b). The need to apply the concept of a tourist friendly destination in the city is due to the development of centres of attraction and promotion (Law, 2002). Thus, Malaysia, through Kuala Lumpur, is seen as a city that is fast becoming a main attraction centre, and a tourism icon of Malaysia (Anuar et al., 2013). With the introduction of the Kuala Lumpur Tourism Policy, Kuala Lumpur's Tourism Development Strategy, Kuala Lumpur's Structure Plan 2020 and the Draft of Kuala Lumpur City Plan 2020 has been seen as the basis for a more viable and competitive tourism development strategy (Anuar et al., 2013); but also as a basis for the development of tourist friendly destination concepts in Kuala Lumpur. Introduction of a tourist friendly destination concept in the city is needed; especially in Kuala Lumpur, that is capable of meeting the demands and needs of tourists, by offering activities, products, and space available for the tourism system (Anuar et al., 2013). Nevertheless, the following questions are raised: i) What is the role and organization of the respondents to the formation of the concept of Kuala Lumpur as a tourist friendly destination? ii) Do the respondents understand the concept of Kuala Lumpur as a tourist friendly destination? iii) 
What are the underlying components of concept formation in Kuala Lumpur as a tourist friendly destination? Accordingly, this study discusses the formation of Kuala Lumpur as a tourist friendly destination, as well as the identification of the attributes of the underlying formation and dimension of the concepts shape.

\section{Tourist Friendly Destination Concept}

Tourist friendly destination is a concept that can give satisfaction to meet tourist's demand and supply through contact and maximum use of activities, products and space without any interruptions or problems (Anuar et al., 2013). Interestingly, this tourist friendly destination concept serves not only the tourists, but also interested parties through tour packages that offer reasonable prices, the distribution and use of infrastructure developments, facilities, accommodations, transportation, and the use of the internet, market rules and a simple way of marketing distribution, supply, and to meet the demands of tourist's expectations; and finally, receive accurate income distribution to target groups of operators, local residents and stakeholders (Anuar et al., 2012c). Basically, the concept of this tourist friendly destination exists because of five factors: changes in the concept of tourism, capacity of tourists to travel, tourism \& destination selection to motivate tourists, tourist's tastes change, and the sharing of public \& private sectors (Anuar et al., 2012c). Therefore, these factors influence the formation of the concept of a perceived tourist friendly destination, through the provision of three dimensions of activities, products, and space tourism system. Through previous studies, the tourism system consists of three elements that are essential and intertwined with each other; namely the elements of activity (Jenkins, 1980; Mill \& Morrison, 1985), space (Urry, 2002; Clarke, 2005) and product (Clarke, 2005). It is also certified by Walsh-Heron \& Stevens (1990), who say that a tourist destination should have a place, activity, and product elements, to create a tourist destination that can provide many options to produce a good image. Accordingly, previous studies clearly indicate that any destination will be influenced by the tourism system in which each system element is inter-related. Similarly, in establishing the concept of a tourist friendly destination, a customer-oriented approach should be used in the tourism system's components, comprising of activities, products, and underutilized space, to create a new experience and maximum satisfaction to tourists; without being bombarded by problems.

\section{Methodology Study}

This study uses a qualitative approach using interviews of 22 respondents, representing four groups of respondents involved in the planning and development of tourism decision-makers: the public sector, the private sector, and the non-profit sector (associations) and professional consultants (Gunn, 2002). A total of 17 questions, divided into three sections, focusing on the views regarding the formation of the concept of a tourist friendly destination in Kuala Lumpur. These questions include the following: i) What is your background? ii) What is your position and role in your organization? iii) Do you play a role in decision-making? iv) Does your organization involve matters of planning, development, or tourism promotion in Kuala Lumpur? v) Is the concept of a tourist friendly destination always preferred when planning, developing, or promoting? The second section is about respondents' understanding of the concept of a tourist friendly destination. Questions in this section include i) Have you ever heard of the concept of a tourist friendly destination? ii) What is the meaning of the concept of tourist friendly destination; based on your experience and understanding? iii) What keywords/dimensions/aspects do you feel are essential for the concept of a tourist friendly destination? iv) Why are they important to describe the concept of a tourist friendly destination v) should the concept of tourist friendly destination be seen in system-dimensional tours through activities, products, and spaces alone? vi) What do you think if Kuala Lumpur applies concepts of a tourist friendly destination? vii) Who do you think is involved in the formation of the concepts, in the context of tourist friendly destination, in Kuala Lumpur and who will be affected when the concept is present? Meanwhile, the third section is about identifying the components in the formulation of the concept of a tourist friendly destination. Questions in this section include: i) What are the underlying components of concept formation of tourist friendly destination; from your experience? ii) Why are these components so important in the development of a tourist friendly destination concept? iii) How do the components of activities, products, and space form the concept of tourist friendly destination, in relation to Kuala Lumpur? The data which was obtained has been analyzed in a narrative form. Next, the data was filtered and irrelevant data was removed, thus describe the data according the respondent's views and perspectives.

\section{Results and Discussion}

Overall, the 22 respondents interviewed had impressive backgrounds, high positions, and experience, with long periods serving with their respective organizations, as well as high levels of education.

"...I worked here in 1986, now my position is Deputy Director... I hold a degree..." (Respondent 1)

"...Education of primary and secondary schools ...and then continues my studies ...make Diplomas ... Master's 
Degree and PhD. Now I work here almost 22 years old ..." (Respondent 12)

Thus, their selection as respondents in this study was considered worthwhile and timely to produce an accurate and relevant tourist friendly destination concept.

Based on the position and role of the respondents in their respective organizations, the questions asked whether the respondents continued to play a role in decision-making concerning tourism. The majority of respondents $(63.6 \%)$ stated that they did not make decisions personally or individually, but all decisions were made in meetings of committees and needed approval from higher officer. This is because discussions by committees are necessary to seek the views of various parties and deliver realistic and reasonable decisions.

"...This decision is actually made in the Committee. No personal decisions. This decision must be made by the Committee members; any development process must obtain the approval of the meeting..." (Respondent 1)

"...I do a strategic planning for tourism in Kuala Lumpur in various fields, such as marketing, promotions, provide advice to the mayor (that are required to be held) about future tourism industry in Kuala Lumpur ..." (Respondent 2)

In addition, questions are also raised to see whether the respondent's organizations were involved in planning, development, or promotion in Kuala Lumpur. These questions were used to look at the organization's involvement in the tourism industry in Kuala Lumpur. The study found that most respondents (36.4\%) said their organizations were involved either in the field of planning, development or tourism promotion in Kuala Lumpur. But the organization's involvement was only based on the interests that could bring a profit.

"...Yes. We have always held promotions, like discounts, promotions, and so on. As a marketing and promotion team, we always work closely with the Department of Tourism Malaysia. The team promotes this business, but also works closely with state organizations, such as City Hall ..." (Respondent 8)

"...Overall, tourism promotion is not available, but from the aspect of food, it is; especially to promote food tourism in Kuala Lumpur ..." (Respondent 15)

The remaining respondents $(50 \%)$ indicated that their organization was not otherwise involved in all areas of planning, development, or tourism promotion in Kuala Lumpur. This was because the scope of the respondent organization's work was beyond this academic field, as well as, other departments within the organization were involved in work concerning planning, development or tourism promotion in Kuala Lumpur.

"...We do not do promotions. Development and planning are made in part because have a Structure Plan and Local Plan. For tourism, have a tourism unit here. This unit will liaise with the Ministry of Tourism. You have to look at the Structure Plan 2004, which explains the idea of the importance of looking at tourism aspects. This Structure Plan 2004 is mentioned regarding the need to set up a tourism unit..." (Respondent 1)

"...My organization is not involved the promotion of tourism in Kuala Lumpur because we are an academic center..." (Respondent 12)

Questions were posed to the respondents directly whether the concept of a tourist friendly destination is always preferred and thought of during planning, development or tourism promotion in Kuala Lumpur. The study found that the majority of respondents $(54.5 \%)$ stated that their priority would be tourist friendly concept while doing planning, development and promotion of tourism in Kuala Lumpur.

"...Yes of course we have included in the plans to translate Kuala Lumpur as a tourist friendly destination. This is reflected in the planning and development done in Kuala Lumpur..." (Respondent 2)

"...Yes. The tourist friendly destination concept is one of the key components in determining the quality of service at the counter and also during the implementation of any program ..." (Respondent 4)

This clearly shows that the concept has always taken priority in planning, development and promotion of tourism in Kuala Lumpur, and is seen through the concept of beneficial and positive effects on tourists in particular. However, only $13.6 \%$ of the respondents indicated "no" and $31.8 \%$ of the respondents did not answer this question at all.

Next, the respondents were questioned on their understanding of the concept of a tourist friendly destination. The study found that the majority of respondents $(63.6 \%)$ had heard about the concept of a tourist friendly destination.

"...Ever hear. Heard from the Ministry of Tourism, but we do not know what actually functions, and the implementation. He just said tourist friendly..." (Respondent 5)

"... Ever, in the tourism industry we always talking about tourism friendly... “ (Respondent 6)

The results of the analysis also showed that the respondents most aware of this concept were those who worked 
directly in the tourism industry, such as front liner in the tourism industry. Thus, the questions continued to show the meaning of the concept of a tourist friendly destination, based on the understanding and experience of the respondents. Results showed that most respondents thought the concept of a tourist friendly destination was a concept that was more focused on the provision of facilities $(40.9 \%)$, provision of hospitality $(31.8 \%)$, provision of a transportation network (31.8\%), the provision of security $(31.8 \%)$, service provision $(27.3 \%)$, language proficiency $(13.6 \%)$, product diversification $(13.6 \%)$, provision of accommodation $(13.6 \%)$, and cultural prominence (13.6\%) in Kuala Lumpur.

"...Tourist friendly destination has become a habit; we see tourists -we will smile. It not only involves the software community, the community is one thing (software) when travellers meet, we smile, we show good ethics...tourism in Kuala Lumpur is heading to the front to see destinations in total, the human factor is the human factor, but the most important is the 70\% tourist friendly facilities, tourist friendly toilets, disabled facilities, car parks for women, introducing bicycles for rent. These all involve hardware..." (Respondent 2)

"...This concept is a good supply of services, beyond the expectations of tourists, use good language (easy to understand) and maintain professionalism..." (Respondent 4)

Thus, the analysis shows that respondents understanding the concept of a tourist friendly destination are a combination of hardware and software to be provided by tourism stakeholders, when tourists travel in a tourism destination, especially Kuala Lumpur.

With regard to use or application of the concept of a tourist friendly destination in Kuala Lumpur, the analysis showed that the majority of respondents (77.3\%) agreed that this concept could be applied in Kuala Lumpur.

"...Because Kuala Lumpur is the capital of Malaysia, and of course, the main attraction for tourists all over the world. If the concept of a tourist friendly destination is successfully carried out, then it will give a good impression to the country in which the foreign tourists who come to Kuala Lumpur will give positive comments back to their country of origin. This will encourage more foreign tourists to come to Malaysia, and thus improve the economy to a greater good. Malaysia would be more known around the world..." (Respondent 11)

"...Kuala Lumpur is a national asset that contributes most to the national economy through the tourism products offered. However, Kuala Lumpur is also a gateway to other states in Malaysia..." (Respondent 15)

For these respondents, Kuala Lumpur is the capital of Malaysia, and of course is the main attraction for tourists all over the world. Even though Kuala Lumpur is also regarded as a tourism hub for Malaysia, it contributes to the national economy through tourism. Hence, of course Kuala Lumpur needs to apply the concept of being a tourist friendly destination.

When asked who should be involved in the formation of the concept of a tourist friendly destination in Kuala Lumpur, the analysis showed that the majority of respondents $(100 \%)$ stated that the government, through Malaysian Embassies, Ministry of Tourism, Tourism Malaysia, Ministry of Information, Communications and Culture, Kuala Lumpur City Hall as the local authority, is the government agency that should be involved in the formation of the concept. In addition, as well as the government, the respondents indicated that even the locals $(18.2 \%)$, private sector $(18.2 \%)$, travel agencies $(18.2 \%)$ and businesses $(9.1 \%)$ were among the responsible stakeholders in developing the concept of a tourist friendly destination in Kuala Lumpur.

"...Who is involved? I think all citizens, from local authorities up to the Ministry of Tourism and Tourism Malaysia..." (Respondent 13)

"...Important to the success of the concept of Tourist Friendly Destinations is the media, restaurants, Malaysian Embassies, government, and travel agencies. They are the ones who will make this concept into tourism and good ..." (Respondent 15)

Hence, close collaboration between stakeholders is the importance in shaping and strengthening the concept of a tourist friendly destination in Kuala Lumpur.

To determine who will be affected when the concept of a tourist friendly destination exists in Kuala Lumpur, the results of the analysis showed that most respondents (40.9\%) agreed that all parties would be adversely affected by the use of the concept of this tourist friendly destination. The intent of parties (from the perspective of the respondents) is not only international tourists who will be affected by the existence of this tourist friendly destination, but also domestic tourists, local residents, the government, the private sector, travel agents, traders, taxi drivers, etc., are also common to tracing the formation of the concept of positive tourist friendly destination.

"...It is not just tourists and foreign tourists, but everyone who uses it. Examples of which include taxis that use, meaning local people, schoolchildren, housewives, disabled people even use the service even earlier, all broad interpretation rather than an isolated scope continues to tour, everything..." (Respondent 15) 
"...The existence of Kuala Lumpur as a tourist-friendly destination can have a big impact on the local economic system that receives the goodness of this program..." (Respondent 17)

However, only a handful of respondents who believe that the formation of the concept of a tourist friendly destination for tourists only affects all types of tourists (international and domestic) (36.4\%), international tourism alone (18.2\%), businessmen (18.2\%), and tourists families $(9.1 \%)$.

"... Everyone will feel. But most feel it would have international and domestic tourists ..." (Respondent 2)

After knowing the level of understanding of the concept of a tourist friendly destination, questions continued to seek the views of the respondents on whether a tourist friendly destination should be formed by the components of activity, products and space alone. This inquiry is necessary, because the development of the tourism industry is reflected in the increase in physical developments, such as infrastructure, facilities, marketing, and promotion of the tourism system in Malaysia. All of these developments are key components in the dimensions of their activities, products and spaces, where it is in accordance with the principles of the tourism system, see the three-dimensional interaction produce an attractive tourism destination image (Jenkins, 1980; Mill \& Morrison, 1985; Walsh-Heron \& Stevens, 1990; Urry, 2002; Clarke, 2005). Consequently, the analysis showed that the majority of respondents (59.1\%) expressed support for the need for the components in the dimensions of activity, activity, products and space seen in the formation of the concept of a tourist friendly destination.

"...Yes, the specified dimension have covered all aspects of being able to make the concept of Tourist Friendly Destinations successful; if the dimension is applied to the full..." (Respondent 11)

"...The concept is very tourist friendly destination in relation to aspects of its activities, products, and spaces. Activity is as a tool to encourage tourists to visit, so that they can receive good offers. The products offered must meet the needs of visitors with optimum quality and safety. Wide scope to add comfort to the visitors..." (Respondent 17)

For the respondents, the components in the dimensions covered in the whole of all aspects of being able to make the concept successful tourist friendly destination in Kuala Lumpur. But the remaining respondents (22.7\%) disagreed with the non-dimensional components of the activity, product and space, but required additional components, such as intangible experiences, information, and application of the concept of think tourism and act tourism, to make Kuala Lumpur more sustainable and competitive.

"... Ooo. This tourist friendly concept, I see there must be information. Because right now, if we go to these tourism spots, they did not show enough information ..." (Respondent 12)

"... Yes, but we require the addition aspects of "intangible experience," as it is a necessary addition, and play a role in enhancing the tourist experience ..." (Respondent 18)

Through the above analysis, it can be concluded that the majority of respondents agreed with the implementation of the components in the three dimensions of their activities, products, and space, to develop the concept of a tourist friendly destination. This is because the dimensions of activity can be seen as an activity that should be done by tourists when they arrive in a holiday destination. Product dimensions can be seen as a service that should be bought by tourists to satisfy their needs and wants, while space can be seen as the physical characteristics that help tourists to meet their needs and requirements.

The questions continued to identify the components in the formation of the concept of a tourist friendly destination. A variety of attributes were given by the respondents to form a component of the concept of a tourist friendly destination. As a result, the majority of respondents indicated services (59.1\%), diversity of products $(40.9 \%)$, hospitality $(40.9 \%)$, facilities $(36.4 \%)$, and mix of activities $(18.2 \%)$, space $(18.2 \%)$, and security $(13.6 \%)$ were the highest of all attributes that should be on every component in the dimensions of their activities, products, and space to develop the concept of a tourist friendly destination.

"...Tourists come for recreation and fun, without problems navigating tourist areas. This is an important aspect. Tourism products and services offering a tourist friendly nature can guarantee high tourist satisfaction and will be more sustainable..." (Respondent 3)

"...The reason is it is able to give an overview of the tourism product offered by the stakeholders as well as the production concept..." (Respondent 16)

For these respondents, these attributes will provide convenience to tourists when implemented in an integrated; while tourists will get satisfaction, benefits and an exciting experience when these attributes are formed by the three dimensional components; thus creating the concept of a tourist friendly destination in Kuala Lumpur. 


\section{Conclusion}

The concept of a tourist friendly destination in Kuala Lumpur is seen as a concept that is formed by the three dimensions of activity, products and space. It should be emphasized that the identification of attributes, thus creating the concept of a tourist friendly destination, is based on the perspective of 22 respondents, representing four groups involved in planning and development of tourism decision-makers, the public sector, private sector, non-profit sectors (associations), and professional consultants. Indeed, the formation of the concept of a tourist friendly destination is very much welcomed by the respondents, who see this as a significant concept in Kuala Lumpur. This is acknowledged by some respondents as follows:

"...Oh of course it is nice; because this concept could help Kuala Lumpur to be world famous. In fact, Malaysia is located on top of the world. So Kuala Lumpur should explore this concept..." (Respondent 13)

"...Yes, the specified dimensions cover all aspects of being able to make the concept of Tourist Friendly Destinations successful-if all dimensions are fully applied..." (Respondent 11)

\section{References}

Anuar, A. N. A., Ahmad, H., Jusoh, H., \& Hussain, M. Y. (2012a). The roles of tourism system towards development of tourist friendly destination concept. Asian Social Science, 8(6), 146-155. http://dx.doi.org/10.5539/ass.v8n6p146

Anuar, A. N. A., Ahmad, H., Jusoh, H., \& Hussain, M. Y. (2012b). The essential elements underlying formation of tourist friendly destination concept: Analysis in micro level. Asian Social Science, 8(13), 59-70. http://dx.doi.org/10.5539/ass.v8n13p59

Anuar, A. N. A., Ahmad, H., Jusoh, H., \& Hussain, M. Y. (2012c). Understanding the factors influencing formation of tourist friendly destination concept. Journal of Management and Sustainability, 2(1), 106-114. http://dx.doi.org/10.5539/jms.v2n1p106

Anuar, A. N. A., Ahmad, H., Jusoh, H., \& Hussain, M. Y. (2013). Policy and tourism development strategy towards tourist friendly destination in Kuala Lumpur. Asian Social Science, 9(2), 180-190. http://dx.doi.org/10.5539/ass.v9n2p180

Clarke, J. (2005). Marketing Management for Tourism. In L. Pender \& R. Sherpley (Eds.), The Management of Tourism (pp. 102-118). London, California, New Delhi: Sage Publications Ltd. http://dx.doi.org/10.4135/9781446214961.n7

Dolnicar, S. (2008). Market segmentation in tourism. In A. Woodside \& D. Martin (Eds.), Tourism Management, Analysis, Behavior and Strategy (pp. 129). Cambridge:CABI. http://dx.doi.org/10.1079/9781845933234.0129

Godfrey, \& Clarke. (2000). The tourism development handbook. London:Thompson.

Gunn, C. A. (2002). Tourism Planning: Basics, Concepts, Cases (4th ed.). In H. Ismail \& T. Baum (Eds.), Urban Tourism in Developing Countries: In The Case of Melaka (Malacca) City, Malaysia. An International Journal of Tourism and Hospitality Research, 17(2), 211-233.

Heath, E., \& dan Wall, G. (1992). Marketing Tourism Destination. A Strategic Planning Approach. Canada: John Wiley and Sons.

Jenkins, C. L. (1980). Tourism policies in developing countrie: a critique. International Journal of Tourism Management, 1(1), 36-48. http://dx.doi.org/10.1016/0143-2516(80)90018-3

Kozak, M. (1999). Destination competitiveness measurement: Analysis of effective factors and indicators. Retrieved May 11, 2012, from http://www-sre.wu-wien.ac.at/ersa/ersaconfs/ersa99/Papers/a289.pdf

Law, C. (2002). Urban Tourism (2nd ed.). Great Britain: Cromwell Press. Trowbridge.

Lipman, G. (2007). Tourism success stories and shooting stars. Proceeding World Tourism Conference (2007), $1-10$.

Mill, R. C., \& Morrison, A. M. (1985). The Tourism System. Englewood Cliffs: Prentice Hall.

Urry, J. (2002). The Tourist Gaze (2nd ed.). London: Sage.

Walsh-Heron, J., \& Stevens, T. (1990). The management of visitors attractions. In J. Swarbrooke (Ed.), The development and management of visitors management of visitors attractions (p. 3). London: Butterworth Heinemann.

\section{Copyrights}

Copyright for this article is retained by the author(s), with first publication rights granted to the journal.

This is an open-access article distributed under the terms and conditions of the Creative Commons Attribution license (http://creativecommons.org/licenses/by/3.0/). 